\title{
Emotional Competence and Leadership Competence: The Role of Demographic Variables (Education and Years of Service) as Moderators
}

Dian Novita Siswanti, Rozainee Khairudin, Fatimah Wati Halim, Norhaiza Khairudin

To Link this Article: http://dx.doi.org/10.6007/IJARAFMS/v11-i3/10810 DOI:10.6007/IJARAFMS/v11-i3/10810

Received: 14 June 2021, Revised: 16 July 2021, Accepted: 30 July 2021

Published Online: 19 August 2021

In-Text Citation: (Siswanti et al., 2021)

To Cite this Article: Siswanti, D. N., Khairudin, R., Halim, F. W., \& Khairudin, N. (2021). Emotional Competence and Leadership Competence: The Role of Demographic Variables (Education and Years of Service) as Moderators. International Journal of Academic Research in Accounting Finance and Management Sciences, 11(3), 108-128.

\section{Copyright: (c) 2021 The Author(s)}

Published by Human Resource Management Academic Research Society (www.hrmars.com) This article is published under the Creative Commons Attribution (CC BY 4.0) license. Anyone may reproduce, distribute, translate and create derivative works of this article (for both commercial and non-commercial purposes), subject to full attribution to the original publication and authors. The full terms of this license may be seen at: http://creativecommons.org/licences/by/4.0/legalcode

Vol. 11, No. 3, 2021, Pg. $108-128$ 


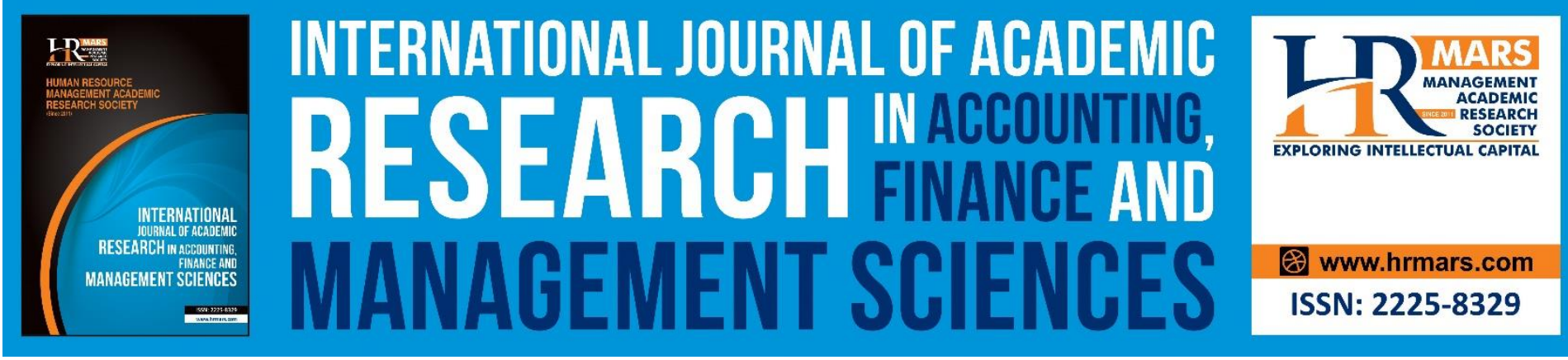

\title{
Emotional Competence and Leadership Competence: The Role of Demographic Variables (Education and Years of Service) as Moderators
}

\author{
${ }^{1}$ Dian Novita Siswanti, ${ }^{2}$ Rozainee Khairudin, ${ }^{3}$ Fatimah Wati \\ Halim, ${ }^{4}$ Norhaiza Khairudin \\ 1,2,3 Faculty of Social Sciences and Humanites, National University of Malaysia, Malaysia, \\ ${ }^{4}$ School of Accountancy, College of Business, Universiti Utara Malaysia, Malaysia \\ Email: rozaineekhai@ukm.edu.my
}

\begin{abstract}
The occurrence of changes in the leadership system resulted in leaders among the government experiencing problems in carrying out their duties and responsibilities within the organization. In short, the problems that often arise in the government bureaucracy, namely the recruitment system and promotion of positions in government bureaucratic institutions are not confined by competent human sources. This is because the system applied only involves an element of subjectivity in the assessment. For this reason, leadership competencies must be possessed by a leader. This competence is related to how a leader can manage emotions properly and appropriately (emotional competence), especially in building interactions with his subordinates. This study aims to propose a conceptual framework of predictable leadership competence with emotional competence. Besides, the researcher also wants to intend to see the effect of demographic variables as a moderator of the relationship between emotional competence and leadership competence. Data was collected through a questionnaire distributed to 300 leaders who work as heads of fields, heads of departments, and heads of offices within the Makassar City Government. The data analysis applied was using inferential analysis in testing the research hypothesis. The results of this study indicate that leadership competence can be predicted by emotional competence by a leader. Besides, the level of education and tenure of a leader has an effect that moderates the effect of emotional competence on leadership competence. Then, the aspects of emotional competence along with education level and years of service also correlated with leadership competence. The findings of this study can provide information for every leader in the government bureaucracy in carrying out their duties to encourage the achievement of organizational goals for success by bringing innovation in the leadership competency model that is built.
\end{abstract}

Keywords: Emotional Competence, Leadership Competence, Education Level, Years of Service 
MANAGEMENT SCIENCES

Vol. 11, No. 3, 2021, E-ISSN: 2225-8329 @ 2021 HRMARS

Introduction

The achievement of organizational goals cannot be separated from a competent leader (Safaria 2004). Leaders are a major factor in aligning and aligning organizational processes (Lewis, Packard, \& Lewis, 2012) because a leader can create commitment and an active role for his subordinates (Idrus et al., 2014). The success of an organization is closely related to the capabilities and skills of the leader of the organization. Organizations without a competent leader will lose direction and orientation. As a result, the organization experiences a decline in productivity, stunted innovation, a climate, and non-adaptive organizational culture. All of these consequences will hinder the pace of the organization in the future or other words will hinder the effectiveness of the organization (Safaria, 2004).

Leaders must have the ability to predict changes that will occur in the future, as well as opportunities for the organization. Leaders are required to be able to use all their potential harmoniously in developing and directing the organization. Leaders do not make decisions based solely on objective facts, rationality, statistical techniques, and in-depth research. Leaders must also be able to use their curiosity, intuition, emotions, deep thoughts, personal experiences, dreams, and hopes. Leaders who rely solely on formal strategic planning may miss opportunities and opportunities. This is due to objective data that is not necessarily able to explain anything about the leader's ability to translate it into something meaningful (Safaria, 2004).

Many studies emphasize that the competence of a leader only revolves around his proficiency in management (Richard, 2004). His background knowledge, experience, and proficiency in management techniques have been considered sufficient in carrying out his function as a leader. An indicator of the success of a leader if they can escort the organization in achieving its goals. Besides, a leader must also have extensive knowledge and a lot of experience. For this reason, organizations need competent leaders.

Competence in Indonesian Government Regulation Number 101/2000 concerning Education and Training for Civil Servant Positions states that competence is a skill and representation possessed by Civil Servants in the form of knowledge, skills, and behavioral attitudes required in carrying out their duties (Salim, 1999). If we look further, the competence in this Government Regulation refers to two directions, namely the ability to describe the ability of hard skills, while for individual representation it describes the soft skills that are expected to be possessed by the leader. Leaders are also required to have these skills in supporting their duties, in this case, leadership competencies, so that the main purpose of the organization in serving the general public can be carried out properly.

However, the current circumstances do not represent this. Leadership changes that occur often cause leaders in government circles to experience problems in carrying out their duties and responsibilities within the organization. In brief, the problems currently faced by the government bureaucracy are: (a) government bureaucratic institutions are not surrounded by competent human sources; (b) a work-centered mechanism that still colors the achievements of the government bureaucracy; (c) supervision of the government bureaucracy is still carried out independently by the government; (d) Corruption, Collusion and Nepotism in the government bureaucracy is still common, which hinders the creation of a competent bureaucracy; (e) bureaucratic positions that only accommodate structural positions and their filling is often not based on the required competencies; ( $f$ ) the arrangement of human resources is not adjusted to the needs and institutional arrangements of the bureaucracy. Other problems that arise are such as the absence of reliable competitiveness in the face of globalization, efforts to place public services in the bureaucratic 
MANAGEMENT SCIENCES

Vol. 11, No. 3, 2021, E-ISSN: 2225-8329 @ 2021 HRMARS

performance have not been realized, and there is still a lot of enthusiasm to increase the number of institutions, institutions, and human resources in the government bureaucracy (Thoha, 2004).

For this reason, organizations in modern times need leaders who have proficiency in hard skills and soft skills. Given leadership can help organizations to maintain focus on achieving the desired targets. For this reason, the individual as a leader must have leadership competence. This competence is related to how a leader can manage emotions properly and appropriately (emotional competence), especially in building interactions with followers and the general public they lead (Swiderski, 2002).

Besides, Siswanti, Khairuddin, and Halim (2018) suggest that leadership competence can be influenced by intellectual, social, emotional, and spiritual aspects. Boyatzis, Goleman, and McBer (1999) suggest that emotional competence is an individual's skill to find, understand, recognize, and use emotional information about oneself that leads to or leads to effective and superior work. Leadership effectiveness can be measured by organizational results, and it is a general function of a leader's behavior. The consideration of these substantive factors will make different competencies and individual accuracy that seem important to a leader, and indirectly have an impact on leadership effectiveness, which will also affect organizational performance. Among all the competencies suggested, the author intends to find emotional competencies that have an impact on leadership and its influence on organizational performance. This paper aims to propose a framework of predictable leadership competence with emotional competence. Besides, the researcher also wants to intend to see the effect of demographic variables as a moderator of the relationship between emotional competence and leadership competence. To achieve this goal, we reviewed previous studies on related topics to identify variables and constraints for framework development.

Therefore, to differentiate from previous research, the researcher involved demographic variables (education and years of service) as a mediator between emotional competence and leadership competence. Starting from the assumptions and phenomena contained in the scope of government agencies which indicate that there is a leader who has good emotional competence, but the competence shown is not optimal. Finally, researchers involve variables of educational status and tenure which can affect the emotional competence of a leader which will also improve and produce competent leaders. Seeing also previous research which reports that educational status (Green, et al., 2011) and tenure (Ejaz, Rehman \& Zaheer, 2009) can affect leadership competencies for every leader. As a result, this research is certainly very important for further investigation. In addition to adding to the literature, it also contributes greatly to producing competent leaders in an organization. The very important contribution of this research, of course, provides evidence that this research is indeed important and urgent to do, especially in the field of government.

\section{Literature Review}

Leadership competence is not only influenced by aspects put forward by Siswanti, Khairuddin, and Halim (2018). Apart from the theory proposed, many other aspects can affect leadership competence. This paper is intended to create a conceptual framework for linking emotional competence with leadership competence moderated by demographic data.

\section{Leadership competence}

According to Siswanti, Khairuddin, and Halim (2018), leadership competence is the ability of a leader to build cooperation in an organization, create open communication, in still 
MANAGEMENT SCIENCES

Vol. 11, No. 3, 2021, E-ISSN: 2225-8329 @ 2021 HRMARS

organizational values and rules in achieving the organization's vision and mission and notice. To increase competence in leading an organization, there should be adequate knowledge, skills, skills and charisma of a leader. Leadership competence means having the ability to develop one's potential to achieve organizational achievement (Wright et al., 2000). Leadership competence is related to the responsibility of each individual in carrying out their duties or making decisions according to their influence in the organization according to their expertise, knowledge, and abilities (Beardwell \& Holden, 1997).

The importance of leadership competence in improving organizational work then developed a competency approach consisting of three aspects by Swiderski (2002), namely: (a) managerial competence, which is the ability that is most often displayed, most attractive and most easily presented as a program in activities outdoor. Managerial competence is a rule, process, procedure, a technique that is used as a tool in improving leadership competence which consists of five factors, namely physiology, environment, safety, technique and administration; (b) Psychological competence, namely the ability that is described as a relationship between personalities and relationships between other individuals. Psychological Competence is divided into three factors. The three factors of this psychological competence include social, psychological and interpersonal relationships; (c) conceptual competence, namely the ability to analyze a leader in making a judgment with a sensible thought process.

In contrast to managerial competence, psychological competence is difficult to measure, so that studies on psychological competence are rarely carried out. Whereas psychological competence has the impression that it is very important to make a leader who has competence in his field. Several studies have shown that the most important thing in increasing leadership competence includes only managerial competence, which then develops with the existence of psychological competence. At present, various findings have been found related to leadership competencies, namely that a leader must have judgment, correct decision making, good problem solving and competence, especially psychological competence (Swiderski, 1981). Psychological competence is referred to by researchers and can affect leadership competence, namely emotional competence.

\section{Emotional Competence}

According to Covey (2008), emotional competence is knowledge about oneself, selfawareness, social sensitivity, empathy, and the ability to communicate well with others. Emotional competence is a more precise determinant of successful communication and leadership. This emotional competence is more of a psychological or psychological approach to a person. Buckingham (2008) argues that great leaders will lead others towards a better future. That is, what determines a leader is his mastery of the future and can be said to be a leader if he can direct people to achieve a better future. Cullen and D'Innocenzo (2004) suggest that leaders who can inspire employees to work to achieve success and the ability to overcome difficult problems are the qualities of leadership.

Yukl (2009) suggests that emotions are strong feelings and are likely to influence cognitive processes and behavior. Emotional competence can help leaders to solve difficult problems, make better decisions, the ability to plan corporate strategy, adapt behavior to situations, and manage critical situations. A leader who has high emotional competence will have greater 
MANAGEMENT SCIENCES

Vol. 11, No. 3, 2021, E-ISSN: 2225-8329 @ 2021 HRMARS

insight into the types of rational or emotional attractiveness most memorable in a given situation.

Robbins and Coulter (2005) define emotional competence as a combination of skills, abilities, and non-cognitive competencies that affect a person's ability to succeed in facing environmental demands and pressures. Denny (2006), through his book, writes, there are five characteristics of emotional competence, namely self-awareness, self-regulation, motivation, empathy, and social abilities. Emotional competence does not only involve understanding and managing one's own emotions but also recognizing other people's emotions so that we can handle a relationship. We must empathize with others and also be self-aware so that we can be sensitive to others.

Emotional competence is the principles learned from emotional intelligence, which will produce the most prominent work in doing work. According to a study conducted by Goleman (1998), emotional competence is a capability principle learned from emotional intelligence, which results in the best performance in the workplace. The difference between emotional intelligence and emotional competence is that emotional intelligence is a property that an individual has since birth, while emotional competence develops the principle of wealth that has been previously owned by each individual. So, henceforth in this study the term emotional competence will be used. Hogan (2003) suggests that emotional competence is the main cognitive capacity for increasing positive results about others and self.

A study conducted by Spencer and Spencer (1993) concluded that emotional competence is a characteristic that underlies individual relationships (between superiors and subordinates) so that an individual has quality in doing a job. Emotional competency programs are thought to be able to achieve the highest work performance in jobs performed by human resources. This emotional competence needs to be applied to improve the ability of leaders in organizations (Boyatzis, et al., 1999; Dolan \& Bradley, 2004). Emotional competence can also affect complex relationships between individuals and their organizations (Love, Edwards \& Wood, 2011).

Furthermore, Gardenswartz, Cherbosque and Rowe (2010) stated that at the organizational stage, it is very important to build emotional competence, especially for a leader in maintaining organizational stability. Individuals with high emotional competence will be able to recognize and manage the impact of emotions on thoughts and behavior, and they develop the ability to assess social dynamics in the workplace and manage relationships within the given context. A leader must properly understand his own and other people's thoughts, feelings and actions through the appearance of emotions which is a new capability in the emotional competency model. This ability consists of making decisions to present emotions to get the desired impact on others and then impressively bringing out these performances during interpersonal interactions (Cote \& Hideg, 2011).

Therefore, a leader who has a high level of emotional competence will be in a better position to regulate his emotions depending on the context of the situation and use the right strategy to get maximum results. The right results can occur when the interacting leader can substantially change other people's behavior, attitudes and emotions in the desired direction. Emotional competence plays an important role in the interactions that occur in the workplace, especially the interactions that occur between leaders and subordinates in joint efforts to achieve organizational goals.

To achieve competence and professionalism in the workplace, it is not only seen from the work that a person produces. However, a worker is required to be more positive, 
MANAGEMENT SCIENCES

Vol. 11, No. 3, 2021, E-ISSN: 2225-8329 @ 2021 HRMARS

approachable, empathetic, and optimistic. A person's emotional competence can include his ability to withstand negative feelings and focus on positive feelings, and it plays a more important role in determining his success in the workplace (Goleman, 1995). Therefore, the principle of emotional competence is self-awareness which is an equally good knowledge of human abilities or limitations, with a deep understanding of the factors between situations that often cause emotions between humans. Boyatzis, Goleman and Mcber (1999) suggest that emotional competence has four components, namely: (1) self-awareness, (2) social awareness, (3) self-management, and (4) social skills. Self-awareness can be expressed in the form of precise and emotional self-awareness and self-confidence. Social awareness is an individual's ability to empathize, organize and be service-oriented. Self-management is an individual's ability to self-control, adapt, have confidence and are achievement-oriented and take initiative. Social and social skills are the ability of individuals to develop the potential of others, have a spirit of leadership and influence, manage conflict and be able to work in teams.

\section{Research Hypotheses}

Emotional competence and leadership competence

A study conducted in India shows that organizational leaders who have low emotional competence in leading the organization will result in low productivity and low management practices (not developing) as well. This can be seen from the creativity and communication he does in discussing the vision and values of the organization in critical situations. This study has been carried out in several organizations to manage human resources consisting of various individuals, beliefs, ideas, and ways of thinking and behavior (Punia, 2003).

In formulating emotional competence from the influence of a leader, emotional competence can be used as a medium to develop competencies in improving personal work and organizational work. As a leader, one must be able to apply various approaches both transactional and transformational approaches to the people in their environment. Efforts to apply these various approaches are closely related to the socio-emotional closeness built by leaders to their workers. The fact is that emotional competence is needed by a leader. The strengthening resulting from the bond between individuals will help both parties to build trust and togetherness based on common interests, in creating the necessary conditions for the achievement of personal and organizational goals (Singh, 2013).

To interact with one another, a leader must be able to carry himself and play personal competencies to achieve organizational excellence. This competence will form an emotional competence in carrying out the roles and responsibilities as a leader, so that leadership competence for a leader is necessary for leaders in an organization, especially organizations engaged in the government sector.

Thus, emotional behavior intelligently addresses basic issues to generate meaningful work and help to reach higher stages of organizational growth and excellence. It helps in the process of developing pleasant work unions in the organization leading to workplace proficiency and the development and enhancement of human resources.

Based on the theory and empirical findings discussed above, there is sufficient evidence to suggest that emotional competence can have a positive impact on leadership competence. So, the researcher offers the following hypothesis:

H1. There is a significant and positive influence between emotional competence and leadership competence. 


\section{The moderating role of education and tenure}

Organizations need leaders who have two abilities, namely the ability in technical knowledge and emotional abilities that will enable them to please their subordinates. Emotional competence can influence the development of the competence and abilities of a leader (Orme \& Langhorn, 2003). Emotional competence is an ability that can be learned, such as having social awareness, or the ability to manage relationships (Goleman, 1998).

Emotional competence plays a very important influence in leadership success (Cavallo, 2004). However, from the aspect of emotional competence, other aspects are thought to be able to predict leadership competence, namely the level of education and tenure of a leader. Many studies have reported the relationship between education and leadership competence. In general, the study of Green, et al (2011) reported that as education increases, leadership competence also increases. Kearney and Gerbert (2008), found that a leader who has obtained a Master's degree is rated at a higher level of leadership competence than those who have a bachelor's degree. Stout-Stewart (2005) found that there was a positive relationship between education level and leadership competence. Besides, tenure also has an impact on leadership competence. The study of Ejaz, Rehman, and Zaheer (2009) found that experience (tenure) had a positive and significant effect on leadership competencies. This means that when a leader has a long working period, the better his leadership competence will be. Based on the above reviews, we formulate the following assumptions:

$\mathrm{H} 2$. There is an influence between emotional competence and leadership competence which will be moderated by the level of education and tenure of a leader.

Leadership is concerned with the interaction of leaders with other individuals. Once there is an interaction involved, emotional awareness and emotional regulation become important factors affecting the quality of the interaction. Good leaders must have a good understanding of their own and others' emotions, and be able to regulate their emotions when interacting with others. This is part of the dimension of emotional competence that has been put forward by Boyatzis, Goleman, and Mcber (1999) suggesting that emotional competence has four components, namely: (1) self-awareness, (2) social awareness, (3) self-management, and (4) social skills. Emotional intelligence has become a critical element in how leaders deal with the complex challenges they face in an organizational environment. Leaders who consider this type of competency have a clear competitive advantage. Besides, educational status and years of service together with aspects of emotional competence explain the correlation with emotional competence. Based on the theoretical formulation and research above, the researcher formulates the following assumptions:

H3. There is a relationship between emotional competence aspects along with demographic variables about leadership competencies.

\section{Method}

Design

This study uses quantitative methods, through the process of collecting data by asking many questions (Creswell, 1994), which aims to determine the direct effect of emotional competence on leadership competence $(\mathrm{H} 1)$. Besides, this study also examines the role of demographic variables (education and years of service) as moderating variables between the 
MANAGEMENT SCIENCES

Vol. 11, No. 3, 2021, E-ISSN: 2225-8329 @ 2021 HRMARS

influence of emotional competence on leadership competence $(\mathrm{H} 2)$. Then the researcher will also examine the relationship of each aspect of emotional competence along with demographic variables about leadership competence $(\mathrm{H} 3)$. The conceptual framework built in this study is presented in Figure 1.

\section{Participant}

This study involved leaders in the city government of Makassar, South Sulawesi $(N=300)$, which was obtained by purposive sampling. The characteristics of the participants in this study were male leaders (73\%), at 11 to 30 years of service (81\%), with postgraduate education status (67\%), who were Muslim (95\%).

\section{Material}

Data collection in this study was carried out through self-reports in the form of a scale consisting of: (a) Emotional Competence Scale. Boyatzis, Goleman, and McBer (1999) arrange them in four aspects, namely self-awareness, social awareness, self-management, and social skills, by adjusting the context in this study. The scale was developed using expert judgments $(\mathrm{N}=7)$ and trials on one hundred and fifty $(\mathrm{N}=150)$ respondents consisting of 23 items with reliability .90. For example, "Subordinates praise my ability in managing the work unit", in the very inappropriate category (1) to very suitable (5), (b) Leadership Competency Scale: Consists of 28 items, referring to Swiderski's theory (2002), compiled by researchers in three aspects, namely managerial competence, psychological competence, and conceptual ability. The leadership competence scale has a reliability of .92 and is measured by a choice of responses from very inappropriate (1) to very suitable (5). For example, one of the items in this study is: "I carefully examine the work of my subordinates".

Researchers conducted a second-order confirmatory factor analysis ( $2^{\text {nd }}$ Order CFA) which tested the emotional competency model. Self-awareness, social awareness, selfmanagement, and social skills are the first-order latent factors that are contained in the second-order latent factor called emotional competence, with each gamma coefficient $(\gamma)$ for all aspects of 1.00. This shows that the four aspects that build the emotional competence variable have a very strong contribution or influence. Structural equation modeling was run with Lisrel version 8.70, using the maximum-likelihood method. We use several goodness-offit indices as recommended by Kline (2005) and Byrne (2001). The fit index for the emotional competence scale showed a good fit in each sample, $\chi 2(p=.000 ; p<.05)$; RMSEA $=.075$, NFI $=.92, \mathrm{CFI}=.92, \mathrm{IFI}=.92$, and PNFI $=.67$ (the bigger the better). Seeing the value of nilai2 and $p$-value which is lower than the predetermined criteria, it is most likely caused by inadequate sample size (Kline, 2005). Given that the parameter $\chi 2$ and $p$-value are very sensitive to the number of samples used in a study. The loading factor value (?i $>0.30$ ) from the results of the $2^{\text {nd }}$ Order CFA model analysis (Table 1) reports that items in aspect 1 move from .44 to .68 , items in aspect 2 move from .31 to .68, items in aspect 3 moves from .30 to .69 , and items in aspect 4 move from .44 to 0.68 , so that all items meet the valid criteria to measure the factor.

(c) Education is revealed by looking at the results of grouping respondents based on their education level, from the demographic data that has been collected. The type of data used in this research is nominal data ( 1 = Bachelor; 2 = Masters; and 3 = Doctor). (d) Data on tenure is obtained by looking at the demographic data of respondents from the results of grouping based on the period of their work. The type of data used in this study is nominal data ( $1=5$ to 10 years; $2=11$ to 30 years). 
Table 1.

Confirmatory factor analysis second-order model ( $2^{\text {nd }}$ Order CFA)

\begin{tabular}{|c|c|c|c|c|}
\hline Scale & $\begin{array}{l}\text { Number of } \\
\text { items }\end{array}$ & ?] $\mathbf{i}$ & $\boldsymbol{V}$ & CR \\
\hline Emotional Competence & 23 & .30 to $.69^{*}$ & 1.00 & $.90^{*}$ \\
\hline Leadership Competence & 28 & .36 to $.70 *$ & 1.00 & $.92 *$ \\
\hline
\end{tabular}

Note. ? $\mathrm{i}=$ Loading factor $*($ ? $\mathrm{i} \geq .30) \gamma=$ Gamma; $\mathrm{CR}=$ Construct reliability * $(\mathrm{CR}>.70)$.

Researchers conducted a second-order confirmatory factor analysis ( $2^{\text {nd }}$ Order CFA) which tested the emotional competency model. Managerial competence, psychological competence, and conceptual ability are the first-order latent factors that are contained in the second-order latent factor called emotional competence. The gamma coefficient $(\gamma=1.00)$ obtained proves that the three aspects that build the leadership competency variable have a very strong contribution. Likewise, the fit statistic showed a good fit for leadership competence, $\chi 2(p=.40 ; p>.05)$; RMSEA $=.011, \mathrm{NFI}=1.05, \mathrm{CFI}=1.00, \mathrm{IFI}=1.05$, and $\mathrm{PNFI}=$ .77 (the bigger the better). The model fit test results report that all the fit indexes have met the criteria so that the theoretical model is following the empirical data. The loading factor value from the analysis of the second-order CFA model reports that the items in aspect 1 (?i

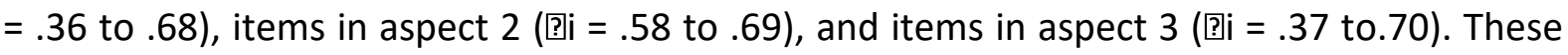
results indicate that each item in each aspect has been classified as valid.

\section{Procedure}

This study requires ethical approval to conduct research. Given that this research involves government agencies, researchers need research permits from the city government of Makassar, South Sulawesi, and the Regional Research and Development Center (Balitbangda). All participants involved in this study had received informed consent and had the consent of all participants. Researchers took research data offline to the leaders, using anonymity for the involved participants.

\section{Data analysis}

The statistical analysis used is inference analysis with ordinal regression model which aims to determine the contribution of emotional competence in predicting leadership competence $(\mathrm{H} 1)$. Hypothesis 2 testing uses the moderated regression analysis (MRA) approach. The last measurement is to test the correlation with the spearmen rho approach on four aspects of emotional competence and demographic variables (education and years of service) on leadership competence (H3), with the help of the JASP software version 0.13.1.0.

\section{Result}

he first hypothesis proposed in this study is that there is a significant influence between emotional competence on leadership competencies possessed by leaders in the Makassar city government. The results of the ordinal regression analysis were used to answer $\mathrm{H} 1$ which is shown in Table 2. 
Table 2.

Variables predicting leadership competence

\begin{tabular}{|c|c|c|c|c|c|c|c|}
\hline \multirow{2}{*}{$\begin{array}{l}\text { Independent } \\
\text { Variable }\end{array}$} & \multirow{2}{*}{ B } & \multirow{2}{*}{$S E$} & \multirow{2}{*}{$B$} & \multirow{2}{*}{$z$} & \multirow{2}{*}{$P$} & \multicolumn{2}{|l|}{$95 \% \mathrm{Cl}$} \\
\hline & & & & & & LB & UB \\
\hline Intercept & -3.538 & .744 & -.013 & -4.752 & $\begin{array}{l}.001 * * \\
*\end{array}$ & -4.997 & -2.079 \\
\hline $\begin{array}{l}\text { Emotional } \\
\text { Competence }\end{array}$ & .041 & .009 & .610 & 4.795 & $\begin{array}{l}.001^{* *} \\
*\end{array}$ & .024 & .058 \\
\hline
\end{tabular}

Note. Nagelkerke $\mathrm{R}^{2}=.108 ;{ }^{*} p<.05 ;{ }^{* *} p<.01 ;{ }^{* *} p<.001$ (2-tailed); LB = Lower bound; UB $=$ Upper bound: Standardized coefficients are reported $(B)$.

The results of ordinal regression analysis reported that there was a significant influence between emotional competence and leadership competence $(p<.001)$. Therefore $\mathrm{H} 1$ in this study is accepted. The Nagelkerke score (Table 2) obtained is .108, which means that emotional competence contributes $10.8 \%$ to leadership competence. Table 2 also shows that the estimated value obtained is positive, so it can be said that the better the emotional competence of the leaders, the better the leadership competence will also be $(\beta=.610 ; 95 \%$ $\mathrm{Cl}=.024$ to .058 ). Visualization of the positive influence of variables that predict leadership competence is presented in Figure 2.

These findings are consistent with the results of research (Siswanti, Khairuddin, \& Halim, 2018), and several theories previously described, namely if the emotional competence of the leader is good, then leadership competence is also good. Then, the researcher proposes the second hypothesis by analyzing the role of education and tenure as moderating variables that directly interact with emotional competence in influencing leadership competencies possessed by leaders in the Makassar city government.

MRA analysis (Table 3 ) shows that there is a significant influence of emotional competence on leadership competence, which is moderated by demographic variables (education). Table 3, shows that there is a positive effect of emotional competence on leadership competence through interaction with the education of a leader $(\beta=.761 ; 95 \% \mathrm{Cl}$ $=.050$ to .318 ). These results also show that leaders with undergraduate and postgraduate education status, the better their emotional competence, the relatively moderate their leadership competence (not good or bad). For leaders with doctoral education status, the better their emotional competence, the better their leadership competence (Figure three). 
Table 3.

The results of the moderator moderated regression analysis (MRA)

\begin{tabular}{|c|c|c|c|c|c|c|c|c|}
\hline \multirow{2}{*}{\multicolumn{2}{|c|}{ Independent Variable }} & \multirow{2}{*}{$B$} & \multirow{2}{*}{$S E$} & \multirow{2}{*}{ B } & \multirow{2}{*}{$t$} & \multirow{2}{*}{$P$} & \multicolumn{2}{|l|}{$95 \% \mathrm{Cl}$} \\
\hline & & & & & & & LB & UB \\
\hline \multicolumn{9}{|l|}{ Step 1} \\
\hline Intercept & & 59.682 & $\begin{array}{l}13.1 \\
78\end{array}$ & - & $\begin{array}{l}4.52 \\
9\end{array}$ & $\begin{array}{l}.001^{*} \\
* *\end{array}$ & 33.748 & $\begin{array}{l}85.61 \\
5\end{array}$ \\
\hline Emotional Competence & & -.136 & .149 & -.121 & -.907 & .365 & -.429 & .158 \\
\hline Education & & 4.859 & $\begin{array}{l}6.19 \\
8\end{array}$ & .165 & .784 & .434 & -7.340 & $\begin{array}{l}17.05 \\
7\end{array}$ \\
\hline $\begin{array}{l}\text { Emotional } \\
\text { Competence*Education }\end{array}$ & & .184 & .068 & .761 & $\begin{array}{l}2.69 \\
9\end{array}$ & $\begin{array}{l}.007^{*} \\
*\end{array}$ & .050 & .318 \\
\hline$R$ & & .837 & & & & & & \\
\hline$R^{2}$ & & .701 & & & & & & \\
\hline Adjusted $\mathrm{R}^{2}$ & & .698 & & & & & & \\
\hline $\mathrm{F}$ & & $\begin{array}{l}230.958 \\
* * *\end{array}$ & & & & & & \\
\hline \multicolumn{9}{|l|}{ Step 2} \\
\hline Intercept & & 118.598 & $\begin{array}{l}24.2 \\
26\end{array}$ & - & $\begin{array}{l}4.89 \\
5\end{array}$ & $\begin{array}{l}.001^{*} \\
* *\end{array}$ & 70.920 & $\begin{array}{l}166.2 \\
75\end{array}$ \\
\hline Emotional Competence & & -0.610 & $\begin{array}{l}0.30 \\
0\end{array}$ & $\begin{array}{l}- \\
0.54 \\
5\end{array}$ & $\begin{array}{l}- \\
2.03 \\
0\end{array}$ & $.043 *$ & -1.201 & -0.019 \\
\hline Years of service & & -35.823 & $\begin{array}{l}12.9 \\
13\end{array}$ & $\begin{array}{l}- \\
0.85 \\
0\end{array}$ & $\begin{array}{l}- \\
2.77 \\
4\end{array}$ & $\begin{array}{l}.006 * \\
*\end{array}$ & - & $\begin{array}{l}- \\
10.41 \\
1\end{array}$ \\
\hline $\begin{array}{l}\text { Emotional } \\
\text { Competence*Years } \\
\text { Service }\end{array}$ & of & 0.583 & $\begin{array}{l}0.15 \\
9\end{array}$ & $\begin{array}{l}1.62 \\
4\end{array}$ & $\begin{array}{l}3.68 \\
1\end{array}$ & $\begin{array}{l}.001 * \\
* *\end{array}$ & 0.271 & 0.895 \\
\hline$R$ & & .571 & & & & & & \\
\hline $\mathrm{R}^{2}$ & & .326 & & & & & & \\
\hline Adjusted $\mathrm{R}^{2}$ & & .319 & & & & & & \\
\hline $\mathrm{F}$ & & $\begin{array}{l}47.741 * \\
* *\end{array}$ & & & & & & \\
\hline
\end{tabular}

Note. ${ }^{*} p<.05 ;{ }^{* *} p<.01 ;{ }^{* * *} p<.001$ (2-tailed); LB = Lower bound; UB = Upper bound: Standardized coefficients are reported $(B)$.

Besides, tenure also has an interaction effect with emotional competence in predicting the leadership competence of a leader in Makassar city government agencies $(\beta=1,624 ; 95 \%$ $\mathrm{Cl}=.271$ to .895$)$. These results also report that leaders with a working tenure of 5 to 10 years, the better the emotional competence they have, the relatively moderate their leadership competence is (not good or bad), while for leaders whose work tenure is 11 to 30 years, it shows that, the better. emotional competence that is owned is also good leadership competence possessed (Figure 3). The results of the MRA analysis have provided evidence that hypothesis $2(\mathrm{H} 2)$ proposed in this study is accepted.

The researcher then took measurements on hypothesis 3 to see the correlation of the four aspects that have the emotional competence variable and demographic variables 
MANAGEMENT SCIENCES

Vol. 11, No. 3, 2021, E-ISSN: 2225-8329 @ 2021 HRMARS

(education and years of service) with leadership competence (Table 4). The correlation coefficient value in the first aspect (KE1) with leadership competence is .364 ( $p=.000)$, which means that there is a positive and significant relationship between KE1 and leadership competence. With the increase in KE1, the leadership competence tends to increase which contributes to $.364^{2}=.132(13.2 \%)$ to leadership competence. The correlation coefficient value in the second aspect (KE2) with leadership competence is .333 ( $p=.000)$, which means that there is a positive and significant relationship between KE2 and leadership competence. With the increase in KE2, the leadership competence tends to increase which contributes to $.333^{2}=.110(11.0 \%)$ to leadership competence.
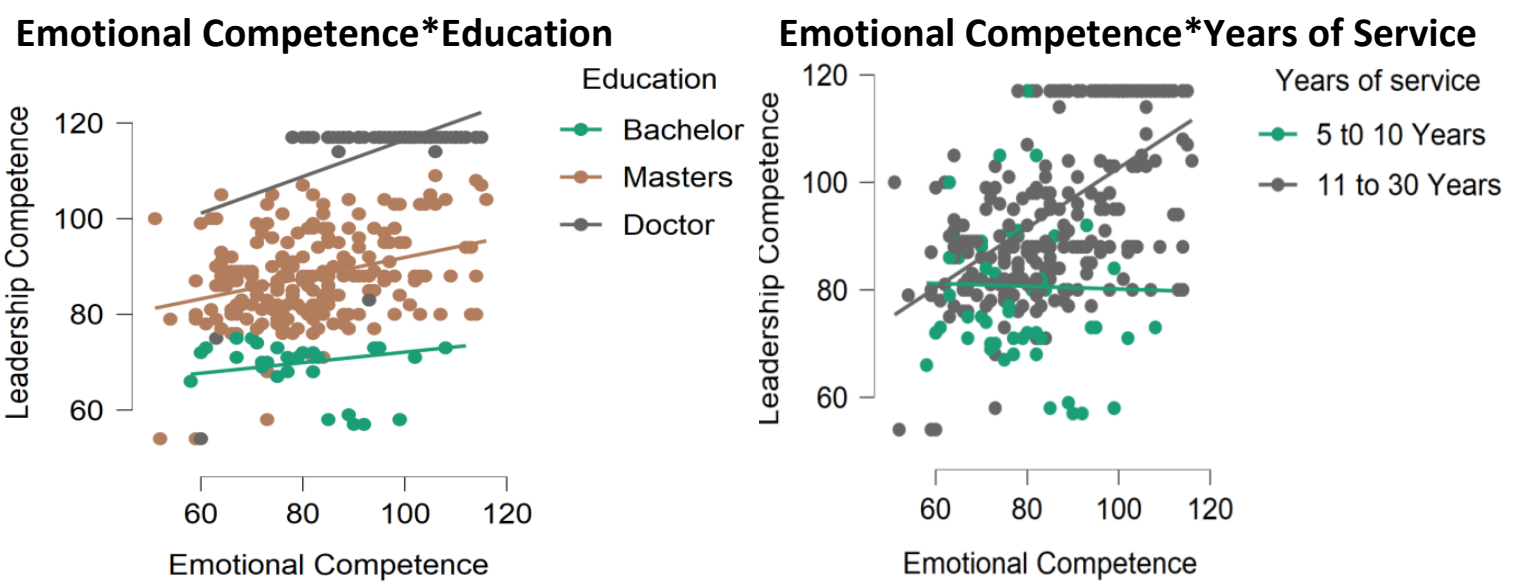

Figure 3. Effects of interaction on leadership competence

The correlation coefficient value in the third aspect (KE3) with leadership competence is $.320(p=.000)$, which means that there is a positive and significant relationship between KE3 and leadership competence. With the increase in KE3, leadership competencies tend to increase which contributes to $.320^{2}=.102(10.2 \%)$ to leadership competencies. The correlation coefficient value in the fourth aspect (KE4) with leadership competence is .430 ( $p$ $=.000$ ), which means that there is a positive and significant relationship between KE4 and leadership competence. With the increase in KE4, leadership competencies tend to increase which contributes to $.430^{2}=.184(18.4 \%)$ to leadership competencies.

The correlation coefficient value on the tenure variable with leadership competence is 356 $(p=.000)$, which means that there is a positive and significant relationship between the leader's tenure and leadership competence. The longer the tenure of a leader, the leadership competence tends to be good with a contribution of $.356^{2}=.126(12.6 \%)$ to leadership competence. The correlation coefficient value on the education variable with leadership competence is .768 $(p=.000)$, which means that there is a positive and significant relationship between the educational status of a leader and leadership competence. The higher the education level of the leaders, the better the leadership competence tends to be with a contribution of $.768^{2}=.589(58.9 \%)$ to leadership competence. The results of the Spearman rho correlation analysis have supported hypothesis 3 proposed in this study (H3 accepted). 
Table 4.

Results of the Spearman rho correlation

\begin{tabular}{|c|c|c|c|c|c|c|c|}
\hline Variable & 1 & 2 & 3 & 4 & 5 & 6 & 7 \\
\hline 1.Self-Awareness & 1 & & & & & & \\
\hline 2.Social-Awareness & $\begin{array}{l}.470 * * \\
*\end{array}$ & 1 & & & & & \\
\hline 3.Self-Management & $\begin{array}{l}.520 * * \\
*\end{array}$ & $\begin{array}{l}.327^{* *} \\
*\end{array}$ & 1 & & & & \\
\hline 4.Social skills & $\begin{array}{l}.570 * * \\
*\end{array}$ & $\begin{array}{l}.403 * * \\
*\end{array}$ & $\begin{array}{l}.685^{* *} \\
*\end{array}$ & 1 & & & \\
\hline 5.Years of Service & $.142 *$ & .022 & $\begin{array}{l}.190 * * \\
*\end{array}$ & $\begin{array}{l}.221^{* *} \\
*\end{array}$ & 1 & & \\
\hline 6.Education & $\begin{array}{l}.270 * * \\
*\end{array}$ & $\begin{array}{l}.233 * * \\
*\end{array}$ & $\begin{array}{l}.258^{* *} \\
*\end{array}$ & $\begin{array}{l}.337^{* *} \\
*\end{array}$ & $\begin{array}{l}.465^{* *} \\
*\end{array}$ & 1 & \\
\hline $\begin{array}{l}\text { 7.Leadership } \\
\text { Competence }\end{array}$ & $\begin{array}{l}.364 * * \\
*\end{array}$ & $\begin{array}{l}.333^{* *} \\
*\end{array}$ & $\begin{array}{l}.320 * * \\
* \\
\end{array}$ & $\begin{array}{l}.430 * * \\
*\end{array}$ & $\begin{array}{l}.356 * * \\
*\end{array}$ & $\begin{array}{l}.768 * \\
* * \\
\end{array}$ & 1 \\
\hline
\end{tabular}

The statistical analysis (regression and correlation) applied in this study has supported $\mathrm{H} 1, \mathrm{H} 2$, and H3. In general, these results indicate that emotional competence has a positive effect on leadership competence through interactions with demographic variables (education and years of service). Therefore, the variables of education and tenure moderate the role of emotional competence on leadership competence. This study specifically proves that leaders who have a high level of education, the better the emotional competence they have, the better the leadership competence that is raised. Likewise for leaders with a tenure of more than 10 years, the better the emotional competence they have, the better the leadership competence shown. Besides, the correlation between every aspect of emotional competence and demographic variables with leadership competence reinforces that it is true that demographic variables can contribute in the form of interactions with emotional competence in predicting leadership competence.

The results of the additional test analysis (Figure 4) show that there are significant differences in emotional competence in terms of educational status $\chi 2(\mathrm{df}=2, \mathrm{~N}=300)=49,367, \mathrm{p}=.000(\mathrm{p}<.005)$, and years of service $(U=4830,500 ; p=.000)$. As well as the leadership competency status of a leader involved in this study, it also shows that there is a significant difference in leadership competence in terms of educational status $\chi 2(d f=2, N=300)=176,198, p=.000(p<.005)$, and years of service ( $U$ $=3316,000 ; p=.000)$. The diagram of the difference in emotional competence and leadership competence based on educational status and tenure can also be seen in Figure four. 


\section{Emotional competence and Education}
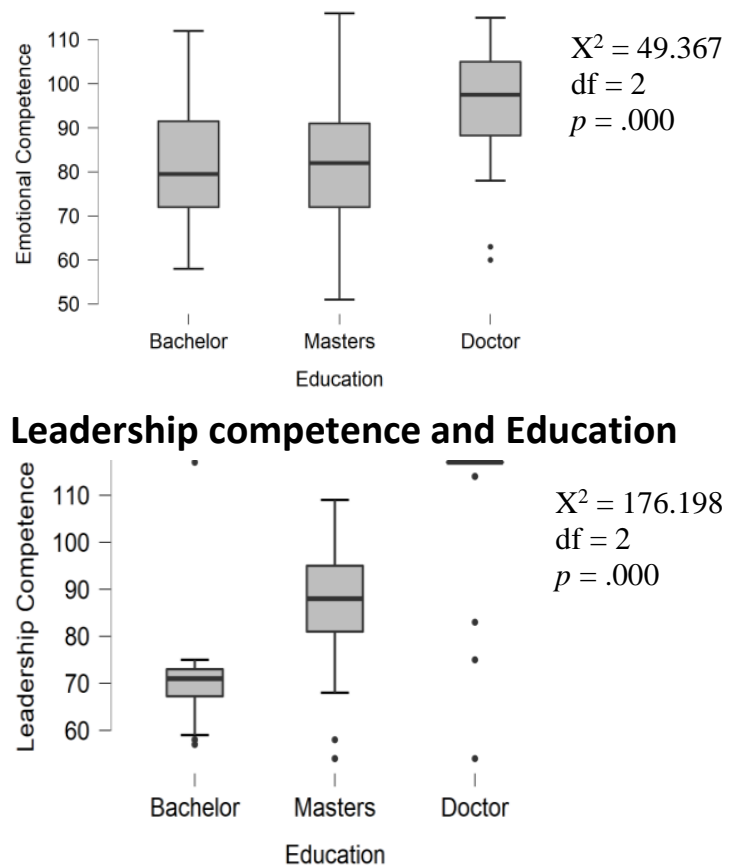

Emotional competence and Years of Service

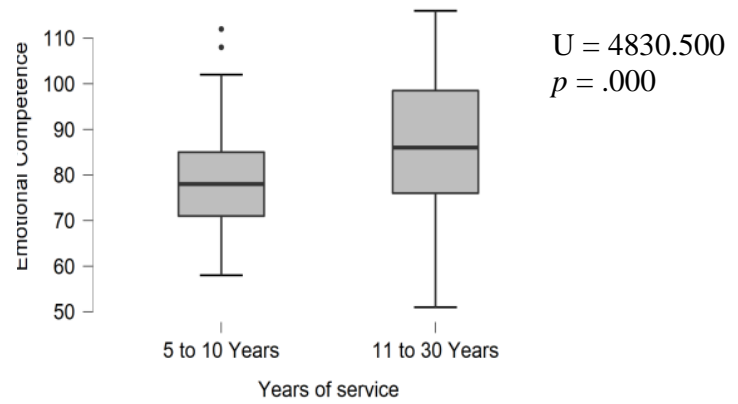

.eadership competence and Years of Service

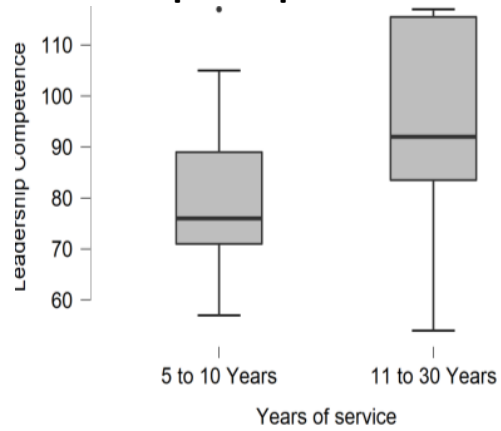

$\mathrm{U}=3316.000$

$p=.000$

Figure 4. Differences in emotional competence and leadership competencies based on education and years of service

The emotional competence variable consists of three levels of education with each mean value $\left(M_{\text {Bachelor }}=126.80 ; M_{\text {Masters }}=131.76 ; M_{\text {Doctor }}=214.21\right)$ which indicates that leaders with doctoral education status tend to have good emotional competence when compared to educational levels. below his level. Besides, researchers also divided the tenure of a leader in seeing their level of emotional competence based on the mean value $\left(M_{5}\right.$ to 10 years $=113.75 ; M_{11}$ to 30 years $\left.=159.12\right)$, which means that a leader with a tenure of over 10 years. years have better emotional competence when compared to leaders who work under 10 years. Likewise, the leadership competency variable consists of three levels of education with each average value $\left(\mathrm{M}_{\text {Bachelor }}=28.77 ; \mathrm{M}_{\text {Masters }}=131.49\right.$; $\mathrm{M}_{\text {Doctor }}=$ 256.98) which shows that leaders with doctoral education status tend to have good leadership competencies when compared to their level. education below his level. Besides, the researchers also divided the tenure of a leader in seeing their level of leadership competence based on the mean value $\left(M_{5}\right.$ to 10 years $=87.18 ; M_{11}$ to 30 years $\left.=165.35\right)$, which means that a leader with tenure above 10 years. years have better leadership competencies when compared to leaders who work under 10 years.

\section{Discussion}

The role of emotional competence on leadership competence

The results of our study indicate that emotional competence has a positive direct influence on leadership competence in the sphere of government. Thus, the first hypothesis proposed in this study is accepted, in this case, the direct effect of emotional competence on leadership competence is significant. Our findings above are supported by research conducted in India where the results show that organizational leaders who have low emotional competence in leading the organization will 
INTERNATIONAL JOURNAL OF ACADEMIC RESEARCH IN ACCOUNTING, FINANCE AND MANAGEMENT SCIENCES

Vol. 11, No. 3, 2021, E-ISSN: 2225-8329 @ 2021 HRMARS

result in low productivity and low management practices (not developing) as well. This can be seen from the creativity and relationships it does in discussing the vision and values of the organization in critical situations. This study was conducted in several organizations to improve human resources consisting of various individuals, beliefs, ideas, and ways of thinking and behaving (Punia, 2003).

In formulating emotional competencies related to their influence on leadership competencies, a leader will become motivated and show more positive thinking in himself as a means of providing motivation and direction for his subordinates. This is an illustration of the positive relationship between emotional competence and leadership competence. The purpose of the role of emotional competence is that emotional competence can make it easier to develop its ability to manage leadership competencies for a leader in an organization.

As a leader, a person must be able to make various approaches both transactional and transformational approaches to the people in their work environment. Efforts to carry out these various approaches are closely related to the socio-emotional closeness that the leader develops to his subordinates. This fact illustrates that emotional intelligence is needed by a leader. The strengthening resulting from the bonds between persons will help both parties to build trust and togetherness based on shared interests, feelings and missions, as well as to create the necessary conditions for achieving organizational goals (Singh, 2013).

To interact with each other, a leader must be able to carry himself and play certain personal competencies, as a form of expertise that can be accepted to achieve organizational goals. Personal competence is emotional competence. In carrying out the roles and responsibilities as a leader, emotional competence is an aspect that plays a very important role in influencing leadership competence for a leader which is necessary for leaders in an organization, especially organizations engaged in government.

Thus, emotional behavior intelligently addresses basic issues to generate meaningful work as well as help to reach higher stages of organizational growth and excellence. It helps in the process of developing a pleasant work association in the organization and ultimately leads to efficiency in the workplace and the development and improvement of human resources. Emotional competence consists of two abilities, namely intrapersonal abilities and interpersonal abilities. Stein and Book (2011) suggest that self-concept is the ability to recognize someone's feelings and to be able to distinguish between them, to know what someone feels and also to know what causes those feelings. Leaders who have emotional competence will be able to do this in this way, thus causing success in the organization.

However, related to this relationship, researchers need to explore to produce more detailed answers related to leadership competencies. The current study also illustrates that the influence between emotional competence and leadership competence is indeed very complex. Our results add to the knowledge of the current problem by proposing two assumptions. First, the influence between emotional competence and leadership competence is moderated by the educational status of a leader. Second, the influence between emotional competence and leadership competence is moderated by the tenure of a leader.

\section{The role of moderation in education and years of service}

The results obtained in our study report that the level of education and tenure affect the influence of emotional competence on the leadership competence of a leader. So, it can be said that education and tenure can act as mediator variables ( $\mathrm{H} 2$ is accepted). Many studies have reported 
INTERNATIONAL JOURNAL OF ACADEMIC RESEARCH IN ACCOUNTING, FINANCE AND MANAGEMENT SCIENCES

Vol. 11, No. 3, 2021, E-ISSN: 2225-8329 @ 2021 HRMARS

related to the effect of education level on leadership competencies. In general, the study of Green, et al (2011) reported that as education increases, leadership competence also increases. Leaders with high educational status, of course, can manage and recognize themselves. It cannot be denied that a leader with a doctoral education status has gone through a lot of pressure, both in terms of academic workloads, conflicts with families, and interactions with other individuals. This pressure is what makes them more capable of accepting thoughts, understanding and regulating emotions in themselves as well as in others (McShane \& Von Glinow, 2010).

In line with this, bad emotional competence among leaders can affect their leadership abilities and competencies in an organization. Leaders who cannot regulate emotions within themselves, will not be adept at regulating the emotions of others such as subordinates and the society they lead, and also have an impact on their ability to behave. This is supported by a study by Newstrom (2011). Leaders with less emotional competence typically show less sensitivity in terms of emotions, so that it is unlikely that they will create meaning for their subordinates. Besides, it has also been reported that a leader with a master's education status is considered to have a higher level of leadership competence than those who have a bachelor's degree (Kearney \& Gerbert, 2008). Likewise, the results of the study by Stout-Stewart (2005) reported that there was a significant positive effect between education level and leadership competence.

The study also reported that respondents who were involved in the study tended to have a service life of 11 to 30 years (81\%). This result is in line with the findings of Siswanti, Khairuddin, and Halim (2018), who reported that the tendencies of a leader's tenure, especially in government agencies, have a working period of 11 years and over. Another study also reported that being a leader in the Indonesian government system is closely related to tenure. Leaders as State Civil Servants (ASN) who work in government begin with group IIla. The rank will continue to increase along with the tenure, the longer the tenure of a State Civil Servant, the higher the rank and class will be and will have the opportunity to become a competent leader (Idrus, et al., 2014). Besides, tenure also has an impact on leadership competence. Research conducted by Abdullah (1991) shows that tenure is one of the factors that can determine the leadership competence of a leader. The tenure can make leaders have good mastery and proficiency at work in an organization. The tenure can also make it easy and quick for leaders to master the situation, build relationships with people in the organization, and have a strategy for action to solve organizational problems. Other studies have also reported that tenure has a significant effect on leadership competence (Ejaz, Rehman, \& Zaheer, 2009).

Correlation of aspects of emotional competence along with demographic variables about leadership competence

The results obtained in our study report that there is a relationship between aspects of emotional competence and demographic variables (education and years of service) with the leadership competence of a leader. So, it can be said that the third hypothesis (H3) proposed in this study is significant. Leadership is concerned with the interaction of leaders with other individuals. To create a good interaction, of course, a leader needs aspects of self-awareness, social awareness, selfmanagement, and social skills. All of these aspects can describe the emotional competence of a leader. These competencies have a real competitive advantage and help in creating leadership competencies in a leader. Besides, educational status and years of service together with aspects of emotional competence explain the correlation with emotional competence. This is in line with previous studies which reported that tenure was positively and significantly related to the aspect of 
INTERNATIONAL JOURNAL OF ACADEMIC RESEARCH IN ACCOUNTING, FINANCE AND MANAGEMENT SCIENCES

Vol. 11, No. 3, 2021, E-ISSN: 2225-8329 @ 2021 HRMARS

leadership, to develop the individual potential of others, develop themselves, support organizational performance, and interpersonal skills where this dimension could report leadership competency variables (Ejaz, Rehman, \& Zaheer, 2009).

\section{Limitations and Future Directions}

Several limitations of our study are necessary. First, respondents to self-reporting were prone to bias and the study design was cross-sectional. The reader must be careful in making conclusions. Thus, replication is needed with other types of action (for example, by comparing the leadership competencies possessed by each leadership division in a government agency) and longitudinal designs. Second, it should be noted that many of the effects observed were rather small. The leadership competence of a leader is influenced by many factors and emotional competence may represent only one and may not be the largest part of these factors. However, a small effect can lead to large results if a large number of respondents are involved (Ellis, 2010). This is a study that needs further exploration. For example, further studies could investigate leadership competencies other than government agencies, and examine whether the findings are the same as when future researchers examined emotional competencies can improve leadership competencies of a leader in the sphere of private agencies, involving many leadership divisions.

\section{Contribution}

Despite the limitations of the research, our study has several theoretical and practical contributions. From a theoretical perspective, this study further extends previous research by examining the moderating effects of education level and tenure on the influence between emotional competence and leadership competence. These results can explain the underlying mechanisms between emotional competence and leadership competence and explain when emotional competence can significantly influence leadership competence. From a practical perspective, our findings can help design effective psychological interventions to improve emotional competence for a leader to improve their leadership competence. Given that the detrimental effect of low emotional competence on leadership competence, interventions to increase emotional competence for a leader can improve leadership competence, to be able to optimally achieve organizational goals. Thus, the finding that bad emotional competence possessed by a leader has a detrimental effect on leadership competence, resulting in complaints and damage in organizational systems. This study certainly has very important implications, especially in the field of government.

\section{Conclusion}

This study answers previous research (Siswanti, Khairuddin, \& Halim, 2018), between emotional competence and leadership competence. The significant results indicate that emotional competence can predict leadership competence for a leader ( $\mathrm{H} 1 \mathrm{accepted}$ ). The measurement results of the second hypothesis indicate that the education and years of service of a leader can explain the direction of influence and significance between emotional competence on leadership competence ( $\mathrm{H} 2$ is accepted). Then the results of the third hypothesis also reinforce that the aspects of emotional competence and demographic variables are correlated with leadership competence (H3 accepted).

However, this study has several limitations that can be considered by future researchers. First, participants in this study were obtained in a non-random way. Therefore, it raises the problem of generalization of the results. Future studies need to involve respondents from various local 
INTERNATIONAL JOURNAL OF ACADEMIC RESEARCH IN ACCOUNTING, FINANCE AND

MANAGEMENT SCIENCES

Vol. 11, No. 3, 2021, E-ISSN: 2225-8329 @ 2021 HRMARS

government agencies in South Sulawesi Province. Second, this study only involved moderating variables in contributing to the influence of emotional competence on leadership competence. Further researchers can involve mediating variables that can accompany emotional competence in predicting leadership competencies such as social competence. Third, this study has measured the role of education level and tenure in moderating the contribution of emotional competence to leadership competence. Future studies can apply other moderating variables such as age, ethnicity, culture, and leadership style, which have the potential to influence the research results.

\section{Declaration of Competing Interest}

The researcher states that there is no conflict of interest.

\section{Acknowledgment}

The researcher thanks the Makassar city government, South Sulawesi Province, which has permitted to carry out the research. Then the researcher also thanks Dwi Yan Nugraha, S.Psi., Who has helped in analyzing and interpreting the research data.

\section{Reference}

Abdullah, S. (1991). Budaya birokrasi indonesia. Jakarta: PT. Pustaka Utama Grafika.

Beardwell, I., \& Holden, L. (1997). Human resource management: A contemporary perspective, (2th Ed.). London: Pitman Publishing.

Boyatzis, R. E., Goleman, D., \& McBer. (1999). Clustering competence in emotional intelligence: Insights from the emotional competence inventory (ECI). Bar-On, R., dan Parker., D. A. (Eds.), Handbook of Emotional Intelligence. San Francisco: Jossey-Bass.

Buckingham, M. (2008). Satu hal yang perlu anda ketahui tentang cara mengelola yang baik, memipin yang baik dan mempertahankan sukses individual. (Terjemahan). Jakarta: Karisma Publishing.

Byrne, B. M. (2001). Structural equation modeling with AMOS: Basic concepts, applications, and programming. Mahwah, NJ: Lawrence Erlbaum Associates.

Cavallo, K. (2004). The emotional intelligence and leadership study. Available www.corpconsultinggroup.com. (Online). Diakses 8 Agustus 2005.

Côté, S., \& Hideg, I. (2011). The ability to influence others via emotion displays: A new dimension of emotional intelligence. Organizational Psychology Review, 1(1), 53-71.

Covey, S. R. (2008). Principle-centered leadership. New York: Simon \& Schuster.

Creswell, J. W. (1994). Research design: Qualitative \& quantitative approaches. London: Sage Publication.

Cullen, J., \& D'Innocenzo, L. (2004). Memaksimalkan kinerja. Yogyakarta: Tugu.

Denny, R. (2006). Success for yourself. Bogor: Mardi Yuana.

Dolan, T., \& Bradley, J. J. (2004). The effect of instruction emotional intelligence of measured by the emotional competence inventory, Perceived stress scale and symptoms of stress checklist. Teaching Journal of the ooi Academy, 1(1).

Ejaz, S., Rehman, K., \& Zaheer, A. (2009). Evaluating effective leadership qualities of managers in dayto-day work of banking sector in Pakistan.1nternational Journal of Management \& Marketing Research (IJMMR), 2(1), 103-111. 
INTERNATIONAL JOURNAL OF ACADEMIC RESEARCH IN ACCOUNTING, FINANCE AND

MANAGEMENT SCIENCES

Vol. 11, No. 3, 2021, E-ISSN: 2225-8329 @ 2021 HRMARS

Gardenswartz, L., Cherbosque, J., \& Rowe, A. (2010). Emotional intelligence and diversity: A model for differences in the workplace. Journal of Psychological Issues in Organizational Culture, 1(1), 74-84.

Goleman, D. (1995). Emotional Intelligence. Diterjemahkan oleh: Hermaya. Jakarta: Gramedia Pustaka Utama.

Goleman, D. (1998). Working with emotional intelligence. New York: Bantam.

Green, M. T., Chavez, E., Lopez, D. M., \& Gonzalez, F. Y. (2011). The impact of education, gender, age, and leadership experience on preferences in leadership. Journal of Business \& Leadership: Research, Practice and Teaching, 7(1), 102-115.

Hogan, R. (2003). Emotional intelligence, emotional effectiveness. Available info@corporateperspectives.com (Online). Diakses 9 Maret 2013.

Idrus, A., Armanu, Sudiro, A., \& Rohman, F. (2014). The Influence of Bureaucratic Leadership, Organizational Culture and Organizational Commitment of Organizational Performance (A Study on SKPD Financial Managers in Makassar Government). Interdisciplinary Journal of Contemporary Research in Business. 5(11), 189-201.

Kearney, E., \& Gebert, D. (2008). Managing diversity and enhancing team outcomes: the promise of transformational leadership. Journal of Applied Psychology, 94, 77-89.

Kline, R. B. (2005). Principles and practice of structural equation modeling. New York: Guilford.

Lewis, J. A., Packard, T. R., \& Lewis, M. D. (2012). Management of human service programs (5th Ed.). Belmont, CA: Brooks/Cole.

Love, P., Edwards, D., \& Wood, E. (2011). Loosening the Gordian knot: the role of emotional intelligence in construction. Engineering, Construction and Architectural Management, 8(1), 5065.

McShane, S. L., \& Von Glinow, M. A. (2010). Organizational behavior: Emerging knowledge and practice for the real world (5th Ed.). New York: The McGraw-Hill Companies, Inc.

Newstrom, J. W. (2011). Organizational behavior. Singapore: McGraw-Hill Education.

Orme, G., \& Ashton, C. (2002). Competency dan emotional intelligence quartely. Competency dan emotional intelligence. Avalilable catarina.udlap.mx/u_dl_a/tales/documentos/lhr/gonzalez_ a_m/bibliografia.pdf (Online). Diakses 27 April 2013.

Punia, B. K. (2003). Emotional intelligence and leadership behavior of Indian executive-An exploratory study. Guru Jambheshwar University-India. Available library.bethlehem.edu/ arb_catalog/Yarmouk_Distribution_Center_List.xls (Online) Diakses 21 April 2012.

Richard, B. (2004). Leadership development at Toronto rehab: Aligning thinking with behavior". Available http://www.Connectiveintelligence.com. (Online). Diakses 2 September 2013.

Robbin, S. P., \& Coulter, M. (2005). Management. 8th Edition. New Jersey: Prentice-Hall.

Safaria, T. (2004). Kepemimpinan. Yogyakarta: Graha Ilmu.

Salim, E. (1999). Good governance dan masyarakat warga. Jurnal Transparansi, 15, 23-27.

Singh, P. (2013). Influence of the leaders' emotionally intelligent behaviors on their employees' job satisfaction. International Business \& Economics Research Journal, 12(7): 799-814.

Siswanti, D. N., Khairuddin, R., \& Halim, F. (2018). The Effect of Spiritual Intelligence, Emotion, and Social Competence to the Leadership Competence. Journal of Physics: Conference Series, 1028(1), p.012193.

Spencer, L. M. Jr., \& Spencer, S. M. (1993). Competence at Work: Models for Superior Performance. Wiley, New York, NY. 
INTERNATIONAL JOURNAL OF ACADEMIC RESEARCH IN ACCOUNTING, FINANCE AND

\section{MANAGEMENT SCIENCES}

Vol. 11, No. 3, 2021, E-ISSN: 2225-8329 (c) 2021 HRMARS

Stein, S. J., \& Book, H. E. (2011). The EQ Edge: Emotional intelligence and your success. John Wiley \& Sons.

Stout-Stewart, S. (2005). Female community college presidents: Effective leadership patterns and behaviors. Community College Journal of Research and Practice, 29, 303-315.

Swiderski, M. (1981). Outdoor leadership competencies identified by outdoor leaders of five western regions. Unpublished doctoral dissertation, University of Oregon, Eugene.

Swiderski, M. (2002). Soft and conceptual skill: The often overlooked components. Available www.wanfangdata.com.cn/qikan/periodical.Erticles/zhhlzz/zhhl2008/0801/080131.htm (Online). Diakses 13 Juni 2012.

Thoha, M. (2004). Perilaku organisasi: Konsep dasar dan aplikasinya. Jakarta: Raja Grafindo Persada. Wright, K., Rowitz, L., Merkle, A., Reid, W. M., Robinson, G., Herzog, B., Weber, D., Carmichael, D., Balderson, T. R., \& Baker, E. (2000). Competency development in public health leadership. American Journal of Public Health, 90(8), 1202-1207.

Yukl, G. (2009). Leading organizational learning: Reflections on theory and research. The leadership quarterly, 20(1), 49-53. 